\title{
Growth and Value Effect on Jakarta Islamic Index: Analysis towards Performance of Sharia Equity Mutual Fund
}

\author{
Sylva Alif Rusmita ${ }^{1,}$ Marhanum Che Mohd Salleh ${ }^{2}$, Puji Sucia Sukmaningrum ${ }^{3}$, \\ Siti Zulaikha ${ }^{4}$
}

\begin{abstract}
This study provides evidence that value and growth stocks are able to explain Net Asset Value of sharia mutual fund. Growth and value stocks in 2013-2017 are used to predict mutual fund profits. Thus, prior to any losses or lower Net Asset Value experienced by customers, investment managers and investors can estimate the profit or loss obtained. This study uses quantitative method with the latest secondary data from companies indexed in the Jakarta Islamic Index and sharia mutual fund data. The results of statistical tests show that growth and value shares equally affect the profit of sharia mutual funds. The growth stock has a larger R-Square than stock value. Meanwhile, the ratios that most affect Net Asset Value of sharia mutual fund are the Return on Equity and Book to Market Value.
\end{abstract}

Keywords: Net Asset Value Sharia Mutual Fund, Sharia Value Stock and Sharia Growth Stock

\begin{abstract}
Abstrak. Penelitian ini membuktikan bahwa growth stock dan value stock mampu menjelaskan Net Asset Value dari mutual fund syariah. Growth stock dan value stock digunakan untuk memperdiksi keuntungan dari mutual fund. Sehingga, sebelum nasabah mengalami keuntungan atau kerugian atas Net Asset Value, manajer investasi dan investor dapat memprediksi kemungkinan keuntungan dan kerugian yang akan didapat. Artikel ini menggunakan metode kuantitatif dengan data sekunder yang diperoleh dari perusahanperusahaan yang terindeks oleh Jakarta Islamic Index dan data mutual fund syariah. Hasil penguajian data statistic menunjukkan bahwa baik growth stock maupun value stock mempengaruhi keuntung mutual fund syariah. Growth stock menunjukkan R-square lebih besar daripada stock value. Sementara itu, rasio yang paling berpengaruh terhadap Net Asset Value pada mutual fund syariah adalah Return on Equity dan Book to Market Value.
\end{abstract}

Kata kunci: Net Asset Value Sharia Mutual Fund, Sharia Value Stock and Sharia Growth Stock 


\section{Introduction}

Investment can be made by investing some real funds as well as financial assets. Tandelilin (2010:2) defines investment as "a commitment to several funds of or other resources being made at the moment, to gain some profits in the future". According to Ibrahim (2013), investment is a highly recommended muamala activity as it allows the properties to become productive and, at the same time, bring benefits to others. In addition, investment also a good medium of wealth rotation if it is done properly. This activity promotes income distribution from wealthy people to the poor. After all, Islam requires Muslims to purify wealth, including from investment activities, through zakat.

One of the investment options is through Capital Market. According to Capital Market Law, Number 8 of 1995, Article 1 paragraph (13), "capital market is an activity concerned with the public offering and securities trading, the public company related to the securities it publishes, as well as the securities-related institutions and professions". In terms of investment instrument, Indonesian Capital Market offers two main products, namely general investment instruments and sharia investment instruments. General investment instruments include shares, bonds and mutual funds, while sharia investment instruments are stocks, sukuk and sharia mutual funds.

One of the instruments that currently receives a high demand in the Indonesian financial market is sharia mutual fund. This fund gives an avenue to investors to raise funds via a sharia-compliant securities portfolio. Since the last ten years until recently, the development of sharia mutual funds in the Indonesian capital market can be regarded as a positive vibe to the country. This is proven by the increase of some sharia mutual funds offered in the market. Wherein 2006, there were only 17 sharia mutual funds valued IDR474 billion. In 2016, the number of sharia mutual funds had increased rapidly to 90 , with the total managed funds amounted to IDR10.2 trillion. In average, within the ten years, the average growth of sharia mutual fund is about $20 \%$ annually.

According to Gowri and Deo (2016), an investment in the mutual funds has fewer risks, like a treasury bill that may be suitable to risk-averse investors. The fund managers will select a portfolio that consists of a balance of funds based on their financial analysis. They will identify less valuable stocks to buy and too expensive stocks to sell to gain from the portfolio returns (Utomo \& Tjandra, 2015).

However, there are some non-transparent sides in the selection of stock portfolios. This is because investors generally do not know the stock portfolios chosen by the fund managers on their behalf. For the sharia mutual fund, the transparency of the contract and information received by investors is crucial. In this 
context, the investors must understand and give their consent on any single items of the investment before proceeding with the investment. These include the level of investment risk, profit, investment portfolio, as well as the terms and conditions of the contract.

According to Haryanto (2014), knowing the performance of mutual funds is important to prevent losses due to the poor performance of the mutual funds. Even though mutual funds are known as less risky investments, investors should realize that there is no guarantee to get a share of profits, dividends or increase in investment capital without proper management. The performance of each mutual fund depends largely on the experience, knowledge, expertise and techniques within the investment process applied by the investment managers. Any deficiency of these conditions will adversely affect the performance of mutual funds, which, in turn, will affect the investors, especially in the monetary aspect. Therefore, mutual fund investors cannot fully rely on the investment manager but also to realize possible risks inherent to their investment that might happen in future. Accordingly, the performance of mutual funds can be accessed via fund performance against a benchmark, historical fund performance, expense ratio, risk-adjusted returns, average maturity and duration, alpha and beta, Portfolio Turnover Ratio (PTR), and also Net Asset Value (NAV).

There are three types of mutual funds: those that invest in stocks (equity funds), those that invest in bonds (fixed-income funds), those that invest in both stocks and bonds (balanced funds), and those that seek the risk-free rate (money market funds). A Stock Mutual Fund or stock fund is a type of mutual fund that invests primarily in individual stocks of publicly-traded companies. Stock mutual funds generally consist of $85 \%$ shares, so it can be predicted that the value of stocks will affect overall mutual fund performance. Therefore, this research tries to compare the value and growth stocks of sharia mutual fund portfolio. This comparison is conducted by classifying stocks into different classes (value stocks and growth stocks) based on market capitalization measurement.

In the hypothesis testing, variables used include return on equity ratio as proxy of profitability, book-to-market ratio as proxy for market value, earnings before interest taxes depreciation and amortization (or EBITDA) / IntExps ratio as proxy of cash flow, Debt / EBITDA ratio as proxy of liquidity, and Earning Per Share (EPS) ratio (Eduardus Tandelin, 2001). It is expected that the results of this study can provide additional insights for investment managers when choosing a portfolio for investors. For investors, this information is useful to predict the risk and return they will receive.

This paper, thus, is structured based on the following manner: after the 
introduction, related literature is reviewed. This is followed by the adoption of methodology and data analysis; and ended with the results and discussions.

\section{Literature Review}

According to Jaballah, Peillex, and Weill (2018), the valuation effect can be explained by different perceptions of investors. In Muslim countries, investors have a positive perception of the sharia compliance because of religious beliefs, while in the United State (US), they have negative perception and reaction towards sharia mutual funds because of negative perception towards islamic religion and also due to the country restrictions of matters associated with sharia compliance.

Accordingly, from a theoretical perspective, this research is developed based on the spirit of portfolio theory and Capital Asset Pricing Models (CAPM) by Sharpe (1964) and Lintner (1967), in which the excess return of assets or portfolios can be explained by its dependence on market risk factors under the assumption of the average portfolio-variance-efficient. One widely known anomaly is the value effect that shows the relationship of stock returns and their value proxies, such as multiples of earnings yield.

Fama and French (2015) have listed five factors consisting of market excess return, size factor (SMB), and book-to-market factor (HML). SMB (Small Minus $\mathrm{Big}$ ) represents a return on a small stock portfolio minus a return on a large stock portfolio, while HML (High Minus Low) represents a return on portfolio value stocks minus returns on portfolio growth stocks. In this research, these five factors could underline that the profitability and investment factors affect the rate of return on assets.

Meanwhile, Tripathi's research (2018), in analyzing the value effect in Indian Stock Market, adopts several variables such as price to book ratio (P / B), price to earnings ratio $(\mathrm{P} / \mathrm{E})$, dividend yield $(\mathrm{D} / \mathrm{P})$, cash flow yield $(\mathrm{C} / \mathrm{P})$, sales to price ratio (S / P) and enterprise value to PBDITA ratio (EV / PBDITA). This study uses conventional risk-adjusted measures and $\mathrm{M}^{2}$ measure and Fama's decomposition measure. According to Athanassakos (2009), variable P / E is a variable that can consistently depict value effects compared with PBV variables. Meanwhile, Leite et al. (2018) state that the variables are evidence of size effect in average stock excess returns, little evidence of value and profitability effects, and some investment effects.

The research from Shaharuddin, Lau, and Ahmad (2017) uses the FamaFrench model to islamic stock. This study contributes to the analysis of the FamaFrench three-factor model by proving the validity of the model using the newly constructed Fama-French factors from the Malaysian Islamic stock market. With 
the generalized method of moments and robustness tests, their results complement the earlier studies by comparing the results over two sub-periods, before and after the financial crises and the fall of Lehman Bros. The results suggest that the reversal of size effects exists after periods of the financial crisis. This is the first attempt to create FF factors and test the model from islamic equity style indices.

This research chooses the almost similar variables used in the previous research, such as profit variable that is Return on Equity; market variable that is book-to-market (BVPS); cash flow variable that is EBITDA / IntExps ratio, liquidity variable that is with Debt / EBITDA, and the Earning Per Share (EPS) ratio of future earnings prospects.

Based on the previous study, the hypothesis of this study is as follows:

1. Return on Equity, book-to-market (BVPS), EBITDA / IntExps ratio, Debt / EBITDA, and the Earning Per Share (EPS) ratio of Value Shock affect the net asset value of mutual funds

2. Return on Equity, book-to-market (BVPS), EBITDA / IntExps ratio, Debt / EBITDA, and the Earning Per Share (EPS) ratio of Growth Shock affect the net asset value of mutual funds

\section{Research Methodology}

This is a quantitative study, which relies on secondary data for statistical analysis and aims to test the hypothesis. Anshori and Iswati (2009: 13) explain that the quantitative approach is a method of research the applies quantitative data and a form of analysis to accept or reject the hypothesis.

\section{Data}

Overall, secondary data is obtained from the Quarterly Financial Report published on the official website of each company and the mutual fund statistics in the official OJK (Financial Service Authority/Otoritas Jasa Keuangan) website from the year 2013 to 2017 .

\section{Population and Sampling}

In terms of sampling technique, this research adopts the purposive sampling method, where the sample is selected based on certain considerations, including:

a. Sharia Mutual Funds that have been in operation during the study period (January 1, 2013 - December 31, 2017); 
b. Sharia Mutual Funds should be registered in OJK;

c. The sample is stock funds that invest at least $80 \%$ of its equity-shaped assets;

d. Sharia shares are listed in the JII index;

e. Companies that publish quarterly financial statements from 2013 to 2017;

f. Stocks classified as large capitalized (bluechip/value) and growing (growth).

The number of sample for value stocks is 100 data from five companies (PT. Astra International, PT. Telekomunikasi Indonesia Persero Tbk, PT United Tractors Tbk, Unilever Indonesia Tbk, PT Wijaya Karya Persero Tbk) with quarterly financial statements during the period 2013-2017 (5 years).

Meanwhile, sample for the growth stock is also 100 data from five companies (PT Pakuwon Jati Tbk, London Sumatra Indonesia Tbk, Kalbe Farma Tbk, Indofood CBP Sukses Makmur Tbk, PT AKR Corporindo Tbk), with quarterly financial statements during the period 2013-2017 (5 years).

Table 1. List of Sharia Mutual Fund 2013-2017

\begin{tabular}{cl}
\hline No & Reksadana Syariah \\
\hline 1 & Batavia Dana Saham Syariah \\
2 & Batavia Dana Saham Syariah \\
3 & Reksa Dana Syariah Bnp Paribas Pesona Syariah \\
4 & Cimb-Principal Islamic Equity Growth Syariah \\
5 & Cipta Syariah Equity \\
6 & Reksa Dana LautandhanaSaham Syariah \\
7 & MandiriInvestaAtraktif-Syariah \\
8 & Reksa Dana Manulife Syariah SektoralAmānah \\
9 & Panin Dana Syariah Saham \\
10 & Reksa Dana PNMEkuitas Syariah \\
11 & Sam Sharia Equity Fund \\
12 & Rd Trim Syariah Saham \\
\hline
\end{tabular}

Sources: Otoritas Jasa Keuangan (Financial Services Authority) 
Table 2. List of Sharia Share Valued and Growth 2013-2017

\begin{tabular}{ccc}
\hline No & Valued Share & Growth-Share \\
\hline 1 & ASII & PWON \\
2 & TLKM & LSIP \\
3 & UNTR & KLBF \\
4 & UNVR & ICBP \\
5 & WIKA & AKRA \\
\hline
\end{tabular}

Sources: Indonesia Stock Exchanges

\section{Definition of Variables}

The variables are defined based on determined characteristics. There are five independent variables chosen in this research which are Profitability (ROE), Market variable (BVPS), Cash flow variables (EBITDA/INTEXP), Liquidity variables (DEBTEBITDA), and Ratio of future earnings prospects (EPS and PER). Meanwhile, The dependent variable is the Net Asset Value Mutual Fund (Y).

\section{Independent Variable}

Value Stock:

\begin{tabular}{lc}
\hline Variables & Symbol \\
\hline Profitability (ROE) & $=\mathrm{X}_{1}$ \\
Market variable (BVPS) & $=\mathrm{X}_{2}$ \\
Cash flow variables (EBITDA/INTEXP) & $=\mathrm{X}_{3}$ \\
Liquidity variables (DEBTEBITDA) & $=\mathrm{X}_{4}$ \\
Ratio of future earnings prospects (EPSand PER) & $=\mathrm{X}_{5}$ \\
\hline
\end{tabular}

Growth Stock

\begin{tabular}{lc}
\hline Variables & Symbol \\
\hline Profitability (ROE) & $=\mathrm{X}_{1}$ \\
Market variable (BVPS) & $=\mathrm{X}_{2}$ \\
Cash flow variables (EBITDA/INTEXP) & $=\mathrm{X}_{3}$ \\
Liquidity variables (DEBTEBITDA) & $=\mathrm{X}_{4}$ \\
The ratio of future earnings prospects (EPS and PER) & $=\mathrm{X}_{5}$ \\
\hline
\end{tabular}




\section{Dependent Variable}

Net Asset Value Mutual Fund (Y)

\section{Model Analysis}

Model analysis of this research is:

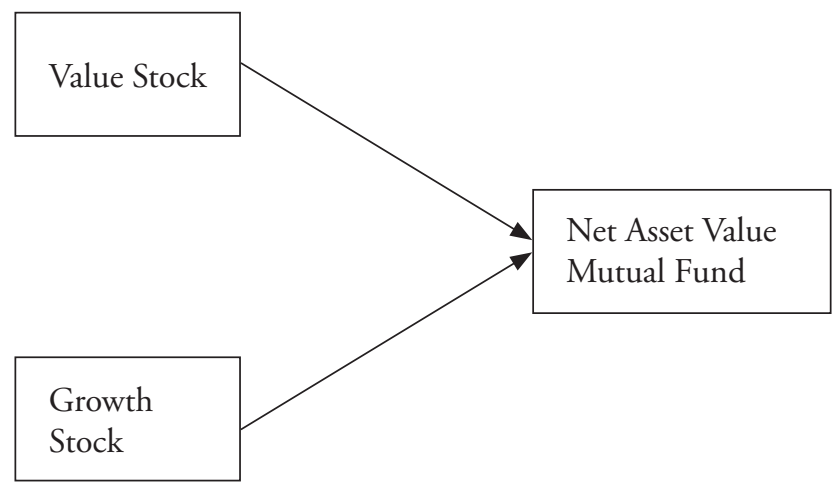

$Y=a+\beta_{1} X_{1}+\beta_{2} X_{2}+\beta_{3} X_{3}+\beta_{4} X_{4}+\beta_{5} X_{5}+e$

$Y=$ Net Asset Value Mutual Fund

$\mathrm{A}=$ Constant

$\beta_{1}-\beta_{5}=$ Coefficient Panel Regression

$\mathrm{X}_{1}=$ Profitability

$\mathrm{X}_{2}=$ Market variable

$\mathrm{X}_{3}=$ Cash flow variables

$\mathrm{X}_{4}=$ Liquidity variables

$\mathrm{X}_{5}=$ Ratio of future earnings prospects

$\mathrm{e}=$ Standard error

$\mathrm{H}_{0}: \mathrm{b} 1=0$ independent variables partial does not have a positive influence on the dependent variable

$\mathrm{H}_{1}: \mathrm{b} 1 \neq 0$, meaning that the independent variables partially have a positive influence on the dependent variable

If the significance number $<0.05$ then $\mathrm{H}_{0}$ is rejected and $\mathrm{H}_{1}$ is accepted 


\section{Data Analysis}

Data in this research is tested by using a PLS model (Pooled Least Square) because this approach is a simple approach in panel data by not considering individual dimension no time dimension. Thus, it is assumed that the behavior between individuals is similar in various period of time (Ajija et al., 2011: 51). However, if the variable of data experiencing disturbance, hypothesis testing should use GLS model or Random Effect because this model is able to estimate interference variables that are interconnected between time and between individuals. Classical Assumption Tests are as follow:

1. Normality Test

2. Heteroscedasticity test

3. Multicollinearity test

4. Autocorrelation test

Meanwhile, the hypothesis tests are:

1. F-Test

The F-test aims to determine the effect of all independent variables in a regression model on the dependent variable. The testing is conducted using a significance level of $0.05(\alpha=5 \%)$. If the probability value is $<0.05$, then the null hypothesis can be rejected, which means all independent variables simultaneously significantly influence the dependent variable.

2. T-Test

The t-test is aimed to prove whether the independent variables individually affect the dependent variable. The testing is conducted using a significance level of $0.05(\alpha=5 \%)$. If the probability value is $<0.05$, then the null hypothesis can be rejected, which means in cateris paribus condition independent variables have a significant effect on the dependent variable. Conversely, if the probability value is $>0.05$, then the null hypothesis cannot be rejected, which means the independent variable has no significant effect on the dependent variable in cateris paribus condition.

3. Coefficient of Determination

The coefficient of determination $\left(\mathrm{R}^{2}\right)$ is used to measure the percentage of the total variation of the dependent variable, which can be explained by the independent variable in the regression line. 


\section{Results}

The result of regression produced by PLS shows that simultaneously all the variables have an effect on Net Asset Value of Sharia Mutual Funds, both in value effect and growth with Prob value> Chi-Square $=0,000$ except the cash flow variable, EBITDAINTEXP

Table 3. Result Significance of Valued Stock to Net Asset Value

\begin{tabular}{lccc}
\hline & Variable & $\begin{array}{c}\text { Coef Value Stock } \\
(\%)\end{array}$ & t-stat \\
\hline Chi & 0.00 & $\mathrm{H}_{0}$ \\
R-Square & 47.2 & & \\
ROE & 44.6 & 0.036 & rejected \\
BVPS & 31.3 & 0.000 & rejected \\
EBITDAINTEXP & 0.07 & 0.295 & accepted \\
DEBTEBITDA & -8 & 0.000 & rejected \\
EPS & -19 & 0,022 & rejected \\
PER & 0.4 & 0,000 & rejected \\
\hline
\end{tabular}

Sources: Author

Based on Table 3 above, overall, ROE, BVPS, and PER have a positive and significant effect on NAV of value stock with 47.2 percent, 31.3 percent, and 4 percent accordingly. On the other hand, liquidity and EPS have a negative influence on NAV. Interestingly, cash flow does not significantly affect the performance of value stock ( $\mathrm{p}$ value $=0.925$ ).

Table 4. Result Significance of Growth Stock to Net Asset Value

\begin{tabular}{lccc}
\hline & Variable & $\begin{array}{c}\text { Coef Growth Stock } \\
(\%)\end{array}$ & t-stat \\
\hline Chi & 0.000 & $\mathrm{H}_{0}$ \\
R-Square & 57.33 & & \\
ROE & 288 & 0.001 & rejected \\
BVPS & 50 & 0.000 & rejected \\
EBITDAINTEXP & 0.12 & 0.008 & rejected \\
\hline
\end{tabular}




\begin{tabular}{lccc}
\hline Variable & $\begin{array}{c}\text { Coef Growth Stock } \\
(\%)\end{array}$ & t-stat & $\mathrm{H}_{0}$ \\
\hline DEBTEBITDA & -4 & 0.000 & rejected \\
EPS & -44 & 0.000 & rejected \\
PER & -0.016 & 0.854 & accepted \\
\hline
\end{tabular}

Sources: Author

Table 4 presents the result of PLS analysis for a growth stock. Overall, based on coefficients value, out of five independent variables, only PER that has not significantly affected NAV of a growth stock. Meanwhile, ROE and BVPS have a bigger influence on the performance of growth stock measured through its NAV (288\% and 50\%) respectively, and EPS have a bigger negative effect at $-44 \%$ towards growth stock. EBITDAINTEXP, on the other hand, is found to be significant with low coefficients.

\section{Discussion}

Based on the regression results, growth stock effect gives greater significance on the Net Asset Value of islamic stock mutual funds. ROE as profitability proxy has a significant influence on the NAV of sharia mutual fund. Therefore, if an investor wants to analyze the performance of sharia stock mutual funds, then investors can estimate from the collection of shares owned by agent companies, especially the value of the company's ROE. Based on the results, growth stock gives more contribution to NAV compared to value stock. This could happen if the investment manager aims to achieve a high profit for the portfolio because the companies which are on the growing stages may provide a high return.

According to Chan and Lakonishok (2004), there are times when investors' sentiment can affect the value of shares of a growing company. Investors in Indonesia have reached an excessive level of optimism about the prospects for growth stocks, such as pharmaceutical, food and distribution industries because the government has planned to improve pharmacy industry, transportation infrastructure as well as rapidly growing industry distribution.

BVPS has the second largest influence after ROE. BVPS is one of the main indicators to analyze whether a stock is expensive or not. However, observation on BVPS should also consider other indicators such as PER. When one buys a stock with BVPS value less than 1.0, it means that the stock's equity value is greater than what is paid. This means there is a discount from its real value. In reality, however, 
although BVPS ratio could be one of indicator in assessing whether the stock is expensive or not, not all shares with BVPS below 1.0 are undervalued shares. It perhaps the stock that has low BVPS because the company was losing, so in later years, its book value decreases. This type of risk may become one of the factors why investment managers reluctant to buy mutual fund portfolios.

Conversely, stocks with high BVPS may not an overvalued stock because the company may offer good prospects and performance, as well as a famous brand. This combination makes their stock price valued in premium, compared to stocks with lower BVPS and lower prospects as well. The investment managers can use the above explanations as considerations in choosing a portfolio for stock mutual funds.

While, generally, high EPS will make net asset value increase, but this time, the result is negative. The negative effect of EPS may be due to the risk that may occur as a "high-risk, high return". On the other hand, EPS cannot be used to determine the fairness of stock prices. Therefore, investment managers must be careful when choosing stocks that have high EPS.

\section{Conclusion}

Based on the above analysis and results, it shows that return on equity (ROE) and book value per share ratios on growth and value stocks have influenced on the Net Asset Value of Sharia Mutual Fund. Investment managers and investors, thus, may assess the portfolio of fundamental variations in a company by using the above variables as the main considerations to observe the performance of Sharia mutual funds in the Indonesian market. Furthermore, other variables can be considered, as well.

\section{References}

Fahmi, I. 2013. Analisis Laporan Keuangan. Bandung: Alfabeta.

Faturrahman, M., Haeruddin. 2011. "Pemodelan Regresi Linier untuk Data Deret Waktu." Jurnal Eksponensial 2(2): 35-42.

Gowri, M \& Malabika Deo. 2016. "Performance Evaluation of Equity Oriented Growth and Dividend Funds of Mutual Funds in India: An Application of Risk-Adjusted Theoretical Parameters." Indian Journal of Finance 10(8): 43-54.

Hadi, N. 2013. Pasar Modal: AcuanTeoretis dan Praktis Investasi di Instrument Keuangan Pasar Modal. Yogyakarta: Graha Ilmu.

Halim, A \& Mamduh M Hanafi. 2009. Analisis Laporan Keuangan. $4^{\text {th }}$ ed. Yogyakarta: UPP STIM YKPN. 
Harahap, Sofyan Syafri. 2009. Analisis Kritis atas Laporan Keuangan. Jakarta: Raja Grafindo Persada.

Jaballah, Jamil, Jonathan Peillex. \& Laurent Weill. 2018. "Is Being ShariaCompliant Worth It?" Economic Modelling 72(C): 353-362. DOI: 0.1016/j. econmod.2018.02.011.

Kasmir. 2013. Analisis Laporan Keuangan. Jakarta: PT Raja Grafindo Persada.

Latan, H. 2014. Aplikasi Analisis Data Statistik Untuk Ilmu Sosial Sains Dengan Stata. Bandung: Alfabeta.

Leite, Andre Luis, Marcelo Cabus Klotzle, Antonio Carlos Figueirido Pinto, \& Aldo Ferreira da Silva. 2018. "Size, Value, Profitability, and Investment: Evidence from Emerging Markets." Emerging Markets Review 36(C): 45-59.

Matos, Paulo, Guilherme Padilha \& Mauricio Benegas. 2016. "On the Management Efficiency of Brazilian Stock Mutual Funds." Operational Research 16(3): 365-399.

Sapian, Ros Zam Zam. 2015. "The Relationship between Trades of Foreign Institutional and Retail Investors and Equity Return (Hubungan antara Dagangan Pelabur Institusi dan Runcit Asing dan Pulangan Ekuiti." Jurnal Pengurusan 44: 93-104.

Shaharuddin, Shahrin Saaid, Wee-Yeap Lau \& Rubi Binti Ahmad. 2017. "Constructing Fama-French Factors from Style Indices: Evidence from the Islamic Equity Market." Emerging Markets Finance and Trade 53(7): 15631572. DOI: 10.1080/1540496X.2016.1278529.

Sutrisno, Bambang \& Irwan Adi Ekaputra. 2016. "Uji Empiris Model Asset Pricing Lima Faktor Fama-French Di Indonesia." Jurnal Keuangan dan Perbankan 20(3): 343-357. (September 2016)

Tripathi, Vanita \& Priti Aggarwal. 2018. "Value Effect in Indian Stock Market: An Empirical Analysis (Review)." International Journal of Public Sector Performance Management 4(2): 146-168.

Utomo, Samuel Kristianto \& Kevin Antony Tjandra. 2015. "Value Effect in Indonesian Stock Returns the Implications for the Equity Mutual Fund Industri." Indonesian Capital Market Review 7(1): 1-14. 